Article

\title{
The First Drying Lake in Chile: Causes and Recovery Options
}

\author{
Rodrigo Valdés-Pineda ${ }^{1,2,3, * \mathbb{D}}$, Pablo García-Chevesich ${ }^{1,4}$, Juan B. Valdés ${ }^{1}$ and \\ Roberto Pizarro-Tapia ${ }^{3}$
}

1 Hydrology and Atmospheric Sciences Department, University of Arizona, J W Harshbarger Bldg., 1133 James E. Rogers Way, Tucson, AZ 85721, USA; pchevesich@mines.edu (P.G.-C.); jvaldes@email.arizona.edu (J.B.V.)

2 Piteau Associates, Water Management Group, 2500 North Tucson Boulevard, Suite 100, Tucson, AZ 85716, USA

3 Technological Center of Environmental Hydrology, University of Talca, Mailbox 747, Avenida Lircay s/n, 3460000 Talca, Chile; rpizarro@utalca.cl

4 Department of Civil and Environmental Engineering, Colorado School of Mines, Golden, CO 80401, USA

* Correspondence: rvaldes@email.arizona.edu; Tel.: +1-520-4816397

Received: 18 November 2019; Accepted: 13 January 2020; Published: 19 January 2020

\begin{abstract}
Located southwest of the city of Santiago (Chile), the Aculeo Lagoon used to be an important body of water, providing environmental, social, and economic services to both locals (mostly drinking water and small-scale agricultural irrigation) and tourists who visited the area for fishing, sailing, and other recreational activities. The lagoon dried completely in May of 2018. The phenomenon has been attributed to the current climatic drought. We implemented and calibrated a surface-groundwater model to evaluate the hydrogeologic causes of the lagoon's disappearance, and to develop feasible solutions. The lagoon's recovery requires a series of urgent actions, including environmental education and significant investment in infrastructure to import water. Ultimately, there are two goals: bringing back historic water levels and ensuring the sustainability of water resources at the catchment scale.
\end{abstract}

Keywords: Aculeo Lagoon; drought; Chile; water scarcity; water demands; water management

\section{Introduction}

The Aculeo Lagoon (Figure 1) is one of the largest natural bodies of water in central Chile, with an historical water surface of $11.7 \mathrm{~km}^{2}$ [1] and a maximum depth of $8 \mathrm{~m}$. It is located $50 \mathrm{~km}$ southwest of Santiago $\left(33^{\circ} 50^{\prime} \mathrm{S}-70^{\circ} 54^{\prime} \mathrm{W}\right.$ ) at an altitude of $350 \mathrm{~m}$.a.s.l. [2]. The lake is located between the inner foothills of La Costa mountain range in the Paine commune of the Metropolitan Administrative Region. Its name comes from the Mapudungun (Mapuche) dialect Acud-Leu, which means "where the river ends". Only small direct tributaries naturally recharge the Aculeo lagoon every winter and sometimes during the summer. The climate of Aculeo is characterized by a well-defined annual cycle with peak of precipitation accumulation in the austral winter (April-September), and much lower values in the austral summer (October-March) [3].

\subsection{Paleoclimatological Records of the Lagoon}

According to paleoclimatological studies [2], the lagoon had dried between 9500 and 7500 cal yr. B.P. Rates of pollen accumulation allowed scientists to infer that the lagoon was a "dry environment" associated with more arid and warmer weather conditions. No evidence has been found of human settlements in the Aculeo Basin during this period. In modern history, this is the first total drying of the lagoon-a socially and environmentally significant phenomenon, given that during the last 100 
years the Aculeo Lagoon has been transformed primarily by the increase in large-scale agricultural activities and other human activities. Therefore, this is the first drying of the lagoon concurrent with the presence of human settlements, and this factor must be considered in the water balance calculations of the catchment, the local aquifer, and its interaction with the lagoon.

From a paleoclimatological perspective, it is also important to consider that the five years in which the lagoon was reduced from its historical levels to complete dryness-as shown in Figure 1-is a short period compared to the resolution of the paleoclimatological processes described by [2]. The authors suggested that the dry conditions persisted during the early- and mid-Holocene; therefore, the paleoclimatological fluctuation of the seasonal lagoon's water levels occurred over more protracted periods of time than the hundred years it took humans to transform the basin, or the ten years of climate drought that supposedly triggered the lagoon dry conditions. These conclusions support the hypothesis that the hydrological processes that triggered the hydrologic drought of the lagoon in the mid-Holocene probably occurred at a much slower rate than those associated with the current drought and drying.

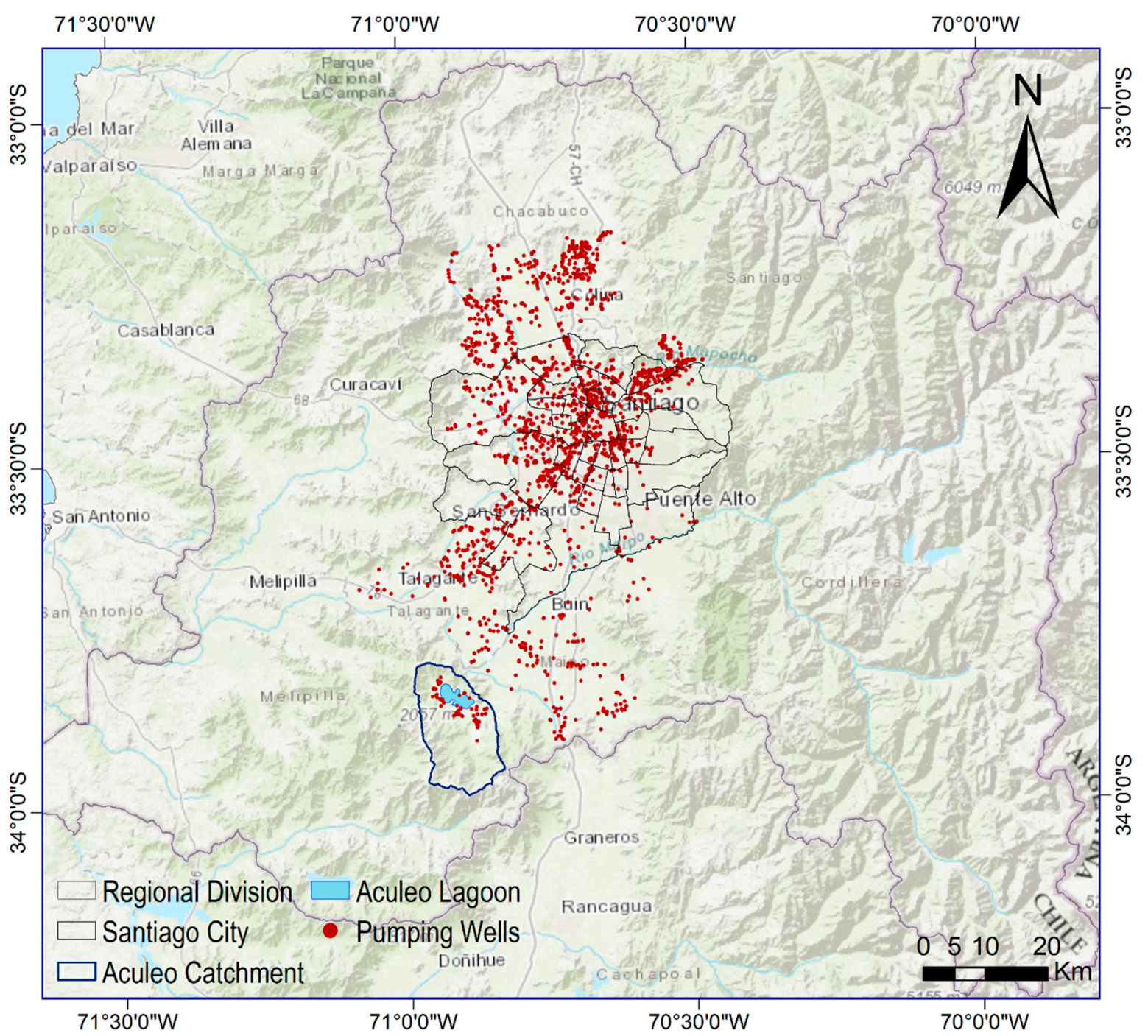

Figure 1. Location of the Aculeo Lagoon within the Metropolitan Region (Santiago), Chile. Approximately 2150 legally registered pumping wells are displayed in the map.

\subsection{Identifying Climatic, Hydrologic, and Socioeconomic Droughts}

Since 2012, the hydrogeological sector in which the Aculeo Lagoon is located has slowly progressed to a state of extreme dryness (Figure 2). Many researchers have linked the total drying of the lagoon, 
which occurred in May 2018, to the climatic mega-drought that has been affecting central Chile since 2010 [4]. It is important to recognize that all types of droughts may originate from a sustained reduction in accumulation, i.e., a climatic drought. From a hydrological perspective it is always important to investigate how the deficit could affect a hydrological or hydrogeological system and be a determining factor in a hydrologic drought. Both climatic and hydrologic droughts are labels that refer to the physical process itself [5]. However, the presence of human settlements adds another concept to the list, the socioeconomic drought; this type of drought occurs when the water demands are higher than the available resources (in Chile, this type of drought is commonly known as water scarcity), resulting in a breakdown of the hydrodynamic balance of a hydrologic system, whether superficial, underground, or the interaction between both. It is possible that the drying of the lagoon stems from a combination of these processes that have interacted over a short period of time.
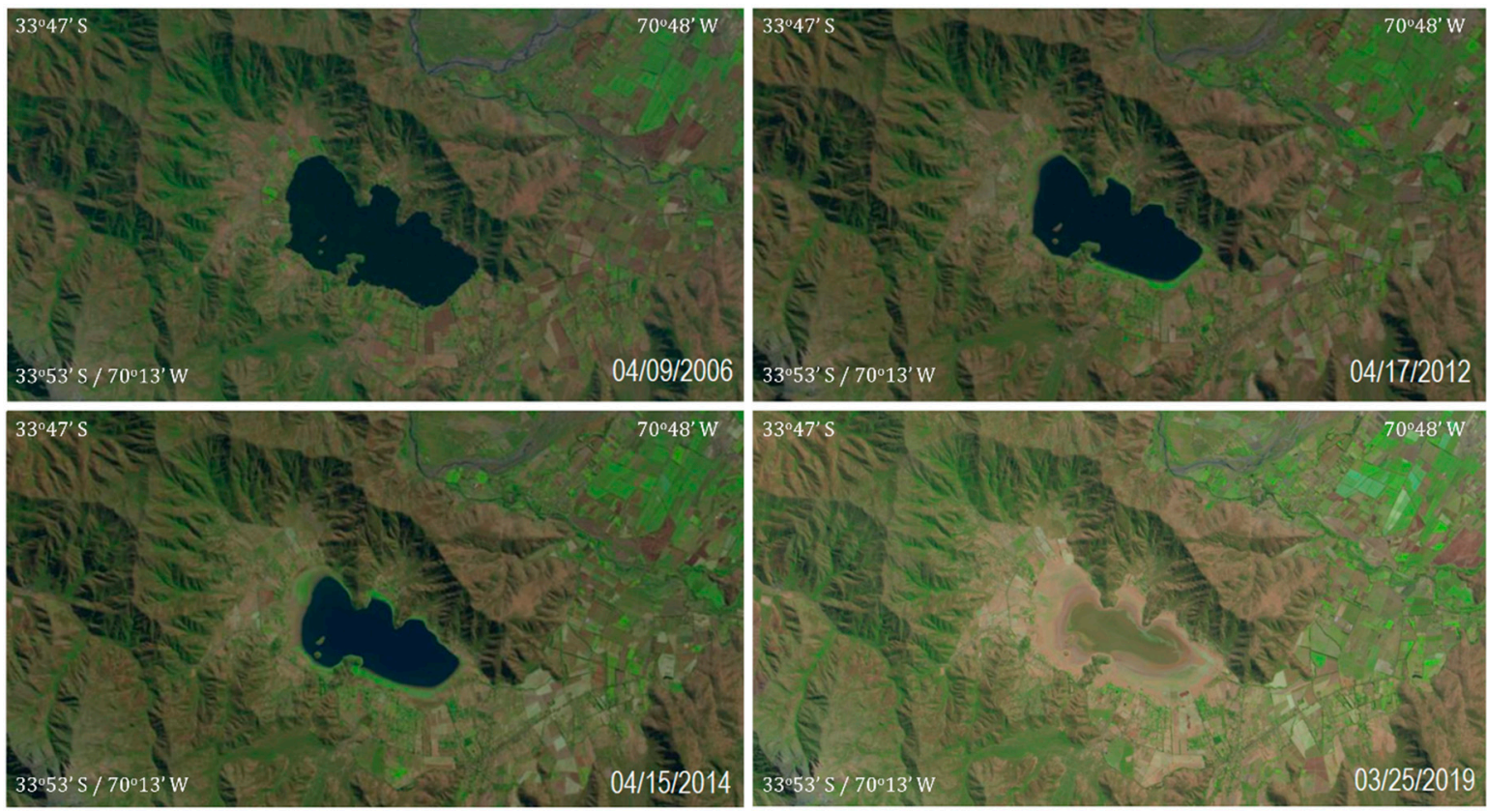

Figure 2. Evolution of the Aculeo Lagoon between 2006 and 2019. Its complete disappearance process started in 2012 and finally occurred on May 2018. The composite is based on Landsat ETM+ images.

\section{Materials and Methods}

\subsection{Hydrogeological Setting of the Aculeo Lagoon}

The initial groundwater levels measured in 57 legally registered pumping wells located in the lagoon's domain ranged from artesian to approximately $20 \mathrm{~m}$ of depth (see Supplementary Material for details about the input data). The main area of the lagoon is formed by deposits of lake sediments with a significant proportion of clays, which decreases toward the northeast portion of the lagoon. The geologic map of Chile [6] shows that the mountain range surrounding the Aculeo Lagoon is characterized by cretacic formations constituted of sedimentary and volcanic sequences located to the west and northeast of the lagoon. Intrusive rocks have been identified mostly in the southeast portion of the lagoon [7]. A lithographical conceptual model for the lagoon's basin was constructed from 57 boreholes and 12 Vertical Electrical Sounding locations (Figure 3). The borehole intervals were obtained from all legal wells drilled and registered at the National Directorate of Water Resources of Chile (DGA); this is public information. Unfortunately, there is not standard required by DGA to perform these tests and, therefore every drilling company provides their own sediment/rock intervals as part of the borehole information. This is the main reason why it was necessary to simplify and homogenize the information available at each location for the final construction of the lithographic model. 
The raw lithography obtained from the boreholes and vertical sounding intervals was classified and simplified using the Soil Texture Calculator (USDA, 2019). The simplification also helped to minimize the convergence errors during the simulation of groundwater fluxes. The simplified conceptual lithographic model was used to construct a surface sedimentary model for the lagoon's basin using the Leapfrog model software [8]. The sedimentary surface chronology was assumed to have the youngest or finer sediments in the upper horizons, and the older or coarser sediments in the lower horizons (see Supplementary Material for details of the categories). All the sediments were also assumed to be seated in a rock basement at approximately 200-300 m of depth. The goodness of fit of the surface chronology model was significant and allowed for the construction of a hydrogeological model with low structural complexity for the simulation of groundwater fluxes in the lagoon and the basin.

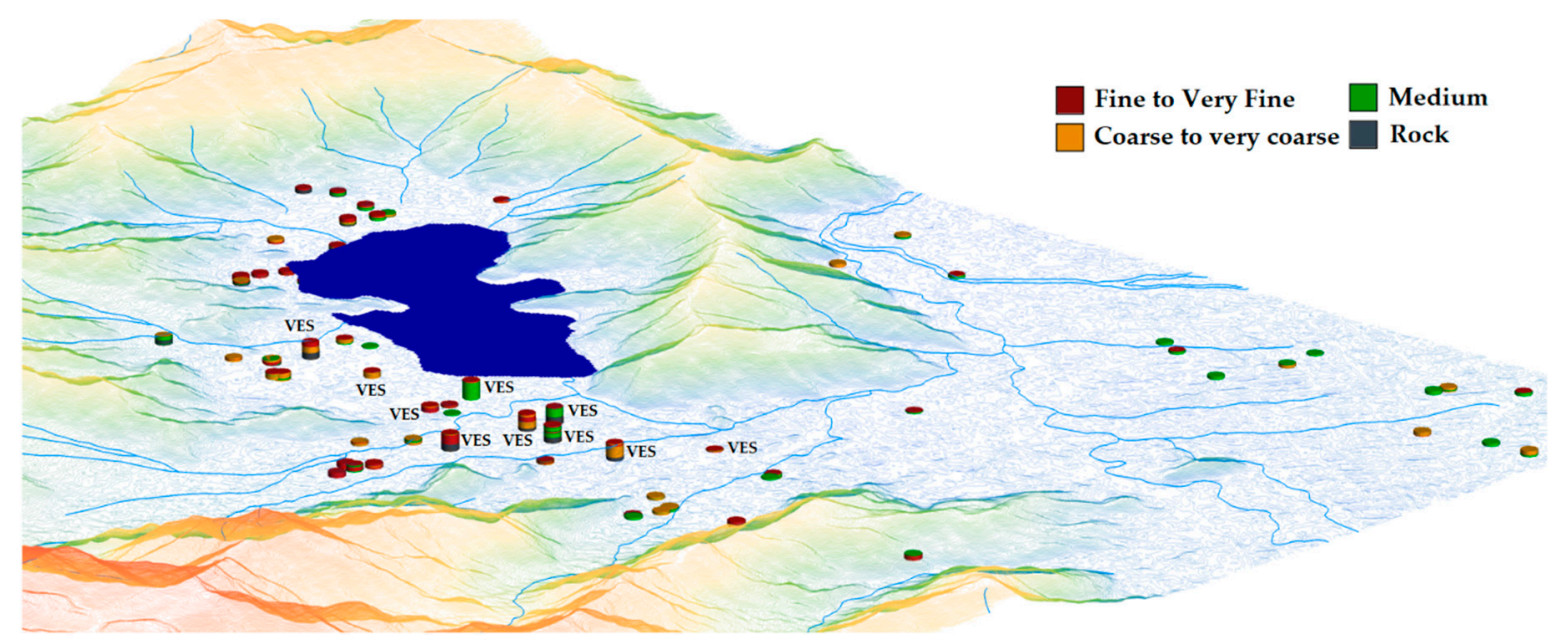

Figure 3. Boreholes and vertical electric sounding (VES) locations used to construct a geological model for the Aculeo domain. The legend represents a simplification of the textural classes found in the lithographic sampling intervals.

\subsection{Understanding the Drying of Aculeo Lagoon}

To understand what other factors, in addition to the climatic drought, could have triggered and accelerated the lagoon's disappearance, we performed the first groundwater modeling for the whole Aculeo basin using MODFLOW [9-12]. MODFLOW is a numerical model that solves the three-dimensional partial differential equation of groundwater flow for a porous medium by using a finite-difference method (see Equation (1)). The model is composed of different packages and programs (see Supplementary Material for details about the packages used in this study) that form the main structure of the input datafiles for the model. The packages used aimed to simulate 5 years of the regional steady and semi-transient daily flow of groundwater in the basin (at $250 \mathrm{~m}$ of spatial resolution), to understand the lagoon-aquifer interaction and the possible causes of the drying. The 5-year period for the simulations was selected because it approximately corresponds to the number of years that it took for the lagoon to dry out. The initial conditions of each 5-year period (2006-2011, 2012-2018, and 2018-2023) were used for the calibrations and simulations. The groundwater flow equation utilized in MODFLOW is defined as

$$
\frac{\partial}{\partial x}\left(K_{x x} \frac{\partial h}{\partial x}\right)+\frac{\partial}{\partial y}\left(K_{y y} \frac{\partial h}{\partial y}\right)+\frac{\partial}{\partial z}\left(K_{z z} \frac{\partial h}{\partial z}\right)+W=S_{S} \frac{\partial h}{\partial t}
$$

where,

- $K_{x x}, K_{x x}, K_{z z}$ are the values of hydraulic conductivity along the $x, y$, and $z$ coordinate axes, respectively, which are assumed to be parallel to the major axes of hydraulic conductivity $(\mathrm{L} / \mathrm{T})$. 
- $\quad h$ is the hydraulic head (L).

- $W$ is a volumetric flux per unit volume representing sources or sinks of water It is negative for groundwater outflow and positive for groundwater inflow of the hydrogeologic system (1/T).

- $S_{S}$ is the specific storage of the porous material $(1 / \mathrm{L})$.

- $\quad t$ is time $(\mathrm{T})$.

\subsection{Aquifer-Lagoon Interaction}

The MODFLOW package LAK3 (Lake package) was used to numerically simulate the aquifer-lagoon interaction. In this package, the lagoon is represented as a water body in contact with the surface grid of the groundwater simulation, which represents the adjacent aquifer. The simulation of the interaction between the Aculeo lagoon and its local shallow aquifer is assumed to occur vertically or laterally. This indicates that the lagoon stage can be significantly affected by the water volume that is transmitted though the lagoon's bed. The transmission of water between the aquifer and the lagoon also depends on the elastic properties of the aquifer, the size of the simulation grid, and the assumptions related to the flow of groundwater through the lagoon's bed. The mathematical formulation utilized to quantify the hydraulic relationship between the lagoon and the adjacent aquifer is based on the application of Darcy's Law (see Equation (2)). The hydraulic level (stage) at the lagoon and the groundwater level in the aquifer can be used to calculate the specific groundwater flux as

$$
q=K \frac{h_{l}-h_{a}}{\Delta l}
$$

where,

- $\quad q$ is the specific (recharge or discharge) flux of water between the lagoon and the aquifer (L/T).

- $K$ is the hydraulic conductivity of the lagoon's bed that separates the lagoon and the aquifer $(\mathrm{L} / \mathrm{T})$.

- $h_{l}$ is the water level in the lagoon $(\mathrm{L})$.

- $h_{a}$ is the groundwater level in the aquifer (L).

- $\Delta l$ is the distance between the measurement's points of $h_{l}$ and $h_{a}$.

Note that the specific flux is positive when the water is recharged from the lagoon to the aquifer $\left(h_{l}>h_{a}\right)$ and negative when the water is discharged from the aquifer to the lagoon $\left(h_{l}<h_{a}\right)$. However, in most natural waterbodies, a mixed flux of water is observed where some areas of the lagoon's bed discharge water from the aquifer to the lagoon and some areas recharge water from the lagoon to the aquifer. Furthermore, Equation (2) also can be expressed as volumetric flux $\left(\mathrm{L}^{3} / \mathrm{T}\right)$ by integrating the specific flux over the transversal area of the plane perpendicular to it as follows.

$$
Q=q A=\frac{K A}{\Delta l}\left(h_{l}-h_{a}\right)=c\left(h_{l}-h_{a}\right)
$$

The parameter $c=\frac{K A}{\Delta l}$ is a term known as conductance $\left(\mathrm{L}^{2} / \mathrm{T}\right)$. This parameter also can be dimensionless assuming a unit area. In the MODFLOW simulation, the area perpendicular to the groundwater flux can have a horizontal component $(X-Y)$, or a vertical component ( $Y-Z$ or $X-Z)$. In the implementation of LAK3, the lagoon occupies the whole volume of each cell with no superposition between cells. The conceptualization of LAK3 also assumes that the lagoon-aquifer interaction occurs in two different materials: (1) the lagoon's bed and (2) the aquifer materials, which depend on the geological model and the discretization applied. More details about the assumptions and limitations of LAK3 package can be found in $[13,14]$. 


\subsection{Water Balance for the Lagoon}

The aquifer-lagoon interaction is updated at every time interval used in the temporal discretization of MODFLOW. The water balance for the lagoon uses Equation (4) to resolve the water level at each time step. The explicit form of the equation is

$$
h_{l}^{n}=h_{l}^{n-1}+\Delta t \frac{p-e-r n f-w-s p+Q_{s i}-Q_{s o}}{A_{s}}
$$

where,

- $h_{l}^{n}, h_{l}^{n-1}$ are the water levels of the lagoon for the current and the previous time interval (L).

- $\Delta t$ is the time interval used in the MODFLOW simulation (T).

- $\quad p$ is the rainfall accumulation for the lagoon in the current time step (L).

- $e$ is the evapotranspiration from the lagoon for the current time step $(\mathrm{L})$.

- $\quad r n f$ is the surface runoff towards the lagoon for the current time step (L/T).

- $\quad w$ is the additional lagoon's inflow or outflow due to anthropogenic influence.

- $Q_{s i}$ is the lagoon's surface inflow from rivers or streams.

- $Q_{s o}$ is the lagoon's surface outflow to river or streams.

- $A_{s}$ is the lagoon's area for the current time step.

- $s_{p}$ is the lagoon's recharge or discharge flow due to its interaction with the adjacent aquifer.

\subsection{Calibration of the Groundwater Model}

The process of calibration was divided in two steps: (1) manual calibration performed by perturbing the parameters utilized in the input files of the simulation packages and (2) performing sensitivity analysis of the results. This calibration was based on the validation of known factors, for example, the water levels, the water volumes, and the total area of the Aculeo Lagoon. On the other hand, the Automatic Calibration process was implemented utilizing UCODE [15], a program developed by the USGS and the US Army Corps of Engineers that allows the implementation of inverse modeling through no lineal regression to estimate the elastic parameters of the aquifer, i.e., hydraulic conductivity, storage, and anisotropy [15]. UCODE utilizes the static levels of the wells to assimilate the response of MODFLOW and modify the parameter values. A comparison between observed and simulated groundwater levels in the lagoon was used to evaluate the calibration performance. The coefficient of determination was significant for each of the three 5-year simulation periods: the base or control year (2006-2011) under normal hydroclimatological conditions, the recorded beginning of the drought (2012-2017), and the total drying of the lagoon (2018-2023).

\section{Results}

The simulation results suggested that the water imbalance was caused by the combination of the following possible factors; (1) high groundwater demands, which were kept constant at about 450-500 $\mathrm{L} / \mathrm{s}$ during the three simulation periods; (2) the drying of the lagoon's natural and/or man-made stream tributaries, which together contributed at least 300-400 L/s to the water body; and (3) the decrease in rainfall defined as climatic mega-drought (see Supplementary Material for details of the rainfall records). This decrease has affected the aquifer recharge which normally ranged between 200 and 250 $\mathrm{L} / \mathrm{s}$ as an average for the basin. All the above factors affected the natural process of water capture, storage, and natural drainage, which resulted in a complete drying over a period of about five years. For example, it has been historically suggested that the pumping rate of $500 \mathrm{~L} / \mathrm{s}$ was sustainable for the lagoon's water volume and levels; however, the simulation showed that this rate is sustainable only under normal hydrogeological conditions, with tributaries running towards the lagoon, and with normal rainfall accumulation. On the other hand, the model showed that this pumping rate was not sustainable for the lagoon's water volume and levels, suggesting that pumping rates should be 
adjusted taking into consideration the most recent hydroclimatological and hydrogeological conditions of the basin and the lagoon. A more detailed discussion of each process is conducted in the following sections of this paper.

\subsection{Capture and Natural Drainage}

The results revealed the presence of an important area of groundwater capture in the Aculeo Lagoon domain. The groundwater captured by the lagoon covers an area greater than $60 \%$ of it (considering an area of $11.5 \mathrm{~km}^{2}$ ) and dominated the water storage in the first $30 \mathrm{~m}$ below ground surface. This capture by the Aculeo Lagoon is probably generated by the combination of several factors, as, for example, the groundwater pressure gradient generated from the mountainous areas surrounding it, or the hydraulic characteristics of the transport phenomena in the Lagoon, which can produce groundwater flow in a vertical (bottom) jet-like manner due to mixing of water with differing temperatures and densities [16]. Additionally, the presence of confining layers or areas of greater water transmissibility, such as those observed in the lagoon, could also lead to the development of artesian gradients toward the water body, which would explain how this natural capture process occurs. The shallow water and groundwater drainage (outflow) occur in a vertical and horizontal jet like-manner in an area close to the outlet (east) of the Aculeo Lagoon (Figure 4). The natural drainage in the lagoon occurs in a smaller area compared to the capture area. However, the rate of groundwater drainage flow from the Lagoon into the local aquifer can be up to four times faster than the captured flow (Figure 5).

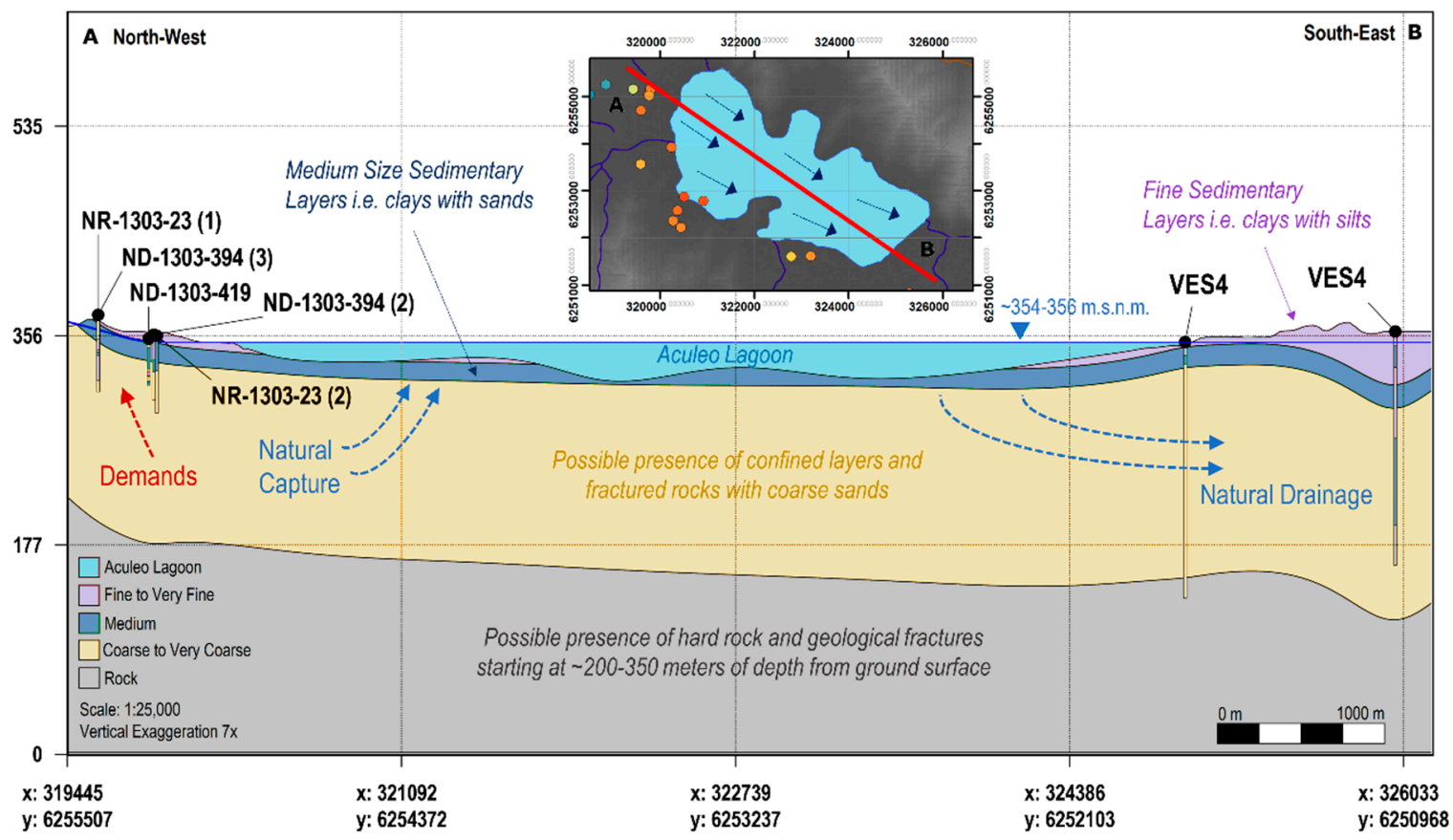

Figure 4. Cross-section along the Aculeo Lagoon (northwest to southeast). The main geological setting together with the hydrogeologic processes of the Lagoon are also conceptualized. 

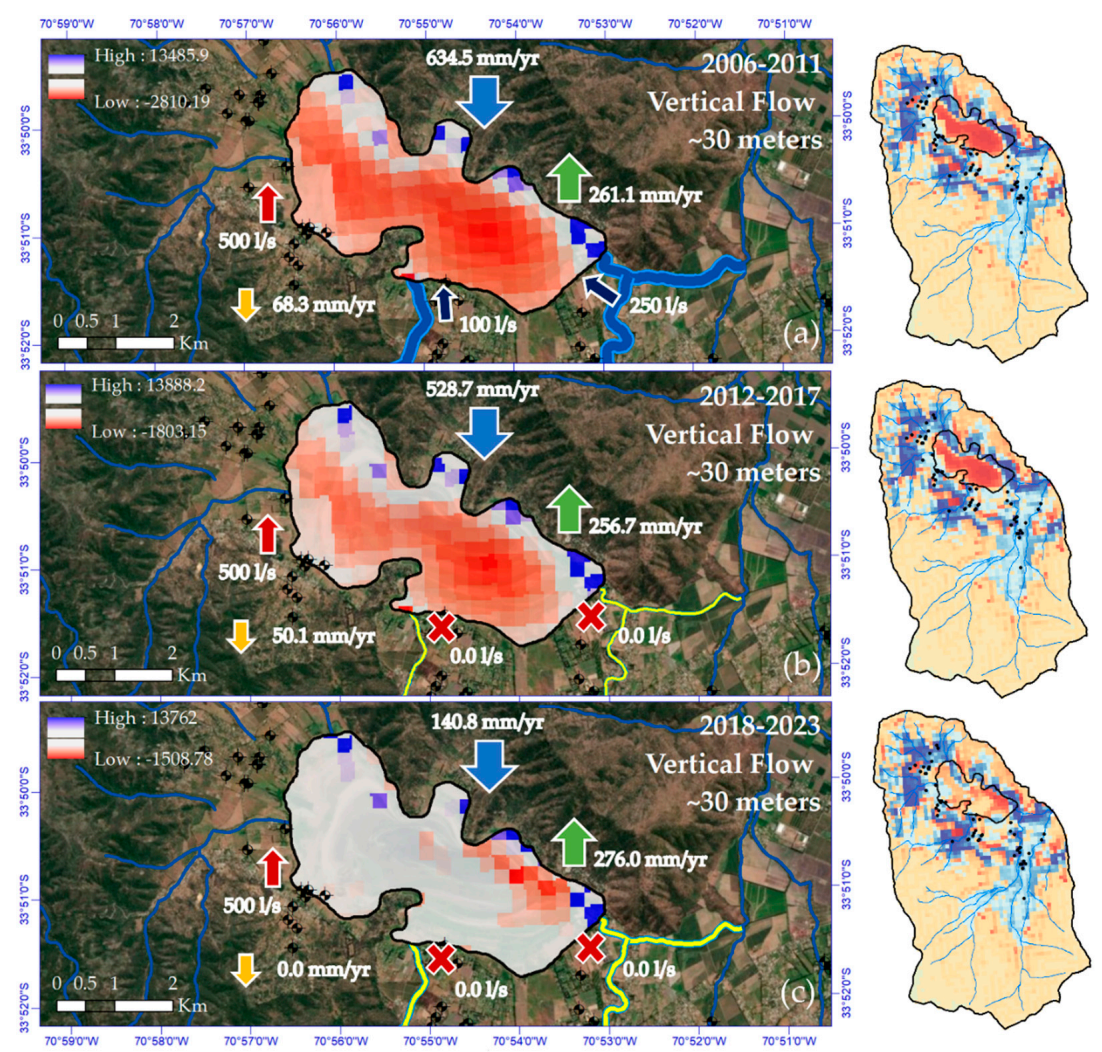

Figure 5. Vertical (recharge and discharge) instantaneous flow $\left(\mathrm{m}^{3} / \mathrm{s}\right)$ at $30 \mathrm{~m}$ deep (boundary between layers 2 and 3 ) at the end of each MODFLOW simulation for the Aculeo basin/lagoon. The (daily time-step) simulation was carried out for a spatial resolution of 250 square meters and using the initial conditions of three 5-year periods (a) 2006-2011, (b) 2012-2017, and (c) 2018-2023. The lagoon's water levels calibrated for each period are 350.92, 349.66, and 345.0 m.a.s.l., which are associated with depths of $5.9,4.6$, and $0 \mathrm{~m}$, respectively. The aquifer area was delineated in concordance with [17]. The fluxes: annual rainfall accumulation (blue arrow) in mm/year; annual evapotranspiration (green arrow) in $\mathrm{mm} /$ year; the recharge (yellow arrow) in mm/year; the pumping rate (red arrow) in L/s; and the lagoon's tributaries (dark-blue arrows) in L/s. The map on the right side shows the discharge and recharge rates for the whole Aculeo basin.

\subsection{Long-Term Variability of Natural Capture and Drainage}

The capture and drainage areas of the lagoon did not vary significantly between the three 5-year simulation periods (2006-2011, 2012-2017, and 2018-2023). For example, at $30 \mathrm{~m}$ deep, it was observed that areal capture decreased by only $4.8 \%$ between 2006 and 2012 (Figure $5 \mathrm{a}, \mathrm{b}$ ), and by approximately $3.9 \%$ between 2006 and 2018 (Figure 5a,c). However, the groundwater flow captured by the lagoon decreased by $21.5 \%$ between 2006 and 2018. On the other hand, the groundwater outflow (or recharge from the lagoon to the aquifer) increased by $25.4 \%$ between 2006 and 2018; it was mainly observed at around the first $30 \mathrm{~m}$ of depth, and it was located mainly in the northeastern and eastern portions of the lagoon (closer to the outlet of the basin).

\subsection{Surface Water Balance}

The Aculeo Lagoon and its local aquifer constantly interact through a process of natural capture (storage gain) and drainage (storage loss). The changes in the volume of the lagoon over the three simulation periods strongly correlate with the changes observed in the rainfall accumulation with the presence of surface tributaries to the lagoon and with the changes observed in the surface water and groundwater drainage of the Lagoon. Between 2006 and 2011 as well as 2012 and 2017, the decrease in rainfall $(\sim 16.7 \%)$ did not generate negative changes in natural recharge. However, this situation changed 
radically during the period 2018-2023, when the amount of rainfall captured by the basin dropped by approximately $77.8 \%$ compared to 2006 , resulting in a total loss of natural recharge (Figure 6). The reduction of rainfall presumably made less water available for the evapotranspiration process; this hydrological partition flux, however, did not reveal significant changes. In fact, evapotranspiration volumes only decreased by 25.9\% (36.6\%) between 2006 and 2011 as well as 2012 and 2017 (2006-2011 and 2018-2023). The simulation results showed that the relationship between rainfall accumulation and evapotranspiration (P/EVT) increased from 20\% to 70\% (Figure 6). The hydrological partition generated accumulated dry conditions and affected the aquifer recharge rates, which dropped dramatically to nearly zero according to the simulation results (see Figure 6).

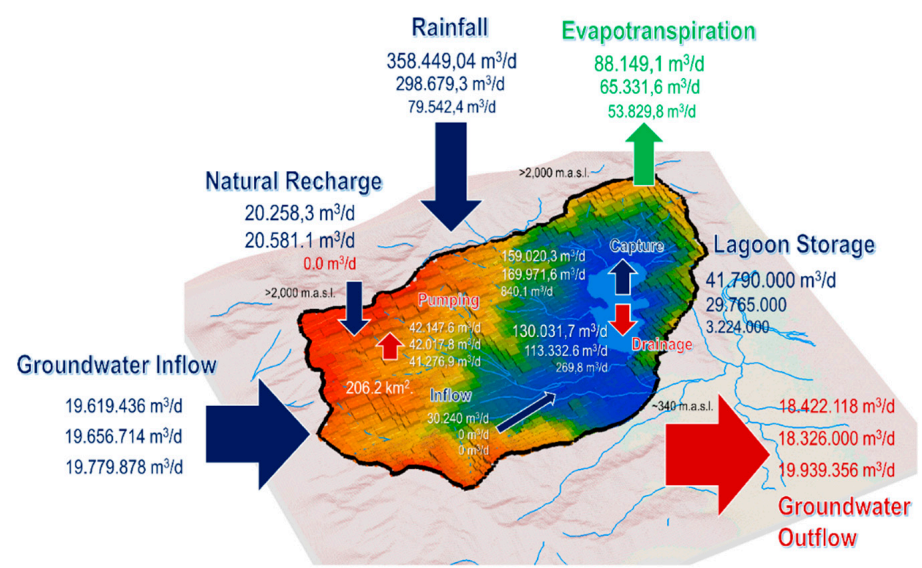

Figure 6. Simulation results of the surface and groundwater balance of the Aculeo basin and its lagoon, for each 5-year simulation period (2006-2011, 2012-2017, and 2018-2023). Each flux of the water balance has three values representing each simulation period, going from normal to dry conditions (top to bottom).

\subsection{Water Balance for the Lagoon-Aquifer Interaction}

The deviation of the surface tributaries to the lagoon, combined with both the sustained decrease in rainfall and the high demands for groundwater pumping (which remained constant over the study period at $\sim 500 \mathrm{~L} / \mathrm{s}$ ), resulted in important changes in the lagoon-aquifer interaction and the lagoon's water balance. Historically, the total volume of groundwater captured (storage gain) by the lagoon was greater than the volume of water drained. The climatic drought reflected in the initial conditions used for the 2018-2023 simulation suggested a significant decrease in the natural recharge and significant reductions in the total capture-drainage rates of the lagoon. The $41.8 \mathrm{Mm}^{3}$ of water present in the lagoon during 2006 was balanced with a net gain or storage (capture minus drainage) of $\sim 20,000 \mathrm{~m}^{3} / \mathrm{day}$ of groundwater, plus $30,000 \mathrm{~m}^{3} / \mathrm{d}$ of surface tributaries. However, during $2018-2023$, the net storage was $\sim 600 \mathrm{~m}^{3} /$ day, and there was zero surface water capture to contribute to this. This reduction in surface water capture, when combined with the constant groundwater demands and climatic drought, have put a significant strain on the groundwater resources (0-30 m deep) in the lagoon area, and the simulation results for the latest period suggest no positive future changes if the final water balance in the basin continues in the same manner. Under this watershed management scheme, the extreme dryness of the Lagoon will continue affecting the economy of the basin, the social well-being in the area, the natural ecosystems, and probably the capacity of this small basin to regulate precipitation recycling processes as described by [18].

\section{Discussion Regarding the Future implementation of a Monitoring and Recovery Plan for the Aculeo Lagoon}

Based on our modeling results, the development of a Monitoring and Recovery Plan (MRP) for the Aculeo Lagoon should consider one or a combination of three feasible options: (1) the recovery of 
natural tributaries, (2) the reduction and regulation of the pumping and storage of groundwater, and (3) an analysis of the feasibility of sustainable water importation alternatives either from groundwater or from nearby basins with available water rights. To be able of efficiently inform the next round of regional groundwater modeling and monitoring strategies, the MRP implemented for the Aculeo Lagoon must contain at least the following elements.

- Recommendations on the establishment of channels for the transportation of surface or underground water from the water source (rivers or pumping wells) directly into the lagoon.

- Identification of the specific locations and characteristics of all the monitoring wells located within the basin, and of the wells that are required to pump water into the lagoon-which will minimize the groundwater drainage flow from the lagoon to the basin's underground exit.

- $\quad$ Establishment of detailed objectives for groundwater levels that will be required to provide water security in the Aculeo basin while also ensuring acceptable surface water levels in the short, medium, and long term. Ideally, such levels should mimic historical annual changes (increases during winter and decreases in the summer), to restore the area's ecological system; in other words, the importation of water should occur annually during winter months.

- Suggestions about the implementation of coupled hydroclimatic-hydrogeologic prediction models that will guarantee advance planning of surface and groundwater resources used and available in the basin, and available for the lagoon.

- $\quad$ Suggestions about the primary legal regulations that should be implemented to better control groundwater extraction or replenishment in the basin and around the lagoon's area, i.e., the enforcement of groundwater permits with real-time monitoring to regulate water extraction or replenishment in the whole basin.

- $\quad$ An environmental education plan to minimize water consumption within the basin. This is just as important as the other elements of an MRP.

All the above will require significant investments that we have estimated to be approximately US $\$ 10 \mathrm{M}$ for the first two years of implementation.

\section{Future Updates and Improvements to the Aculeo Lagoon's Hydrogeological Model}

The implementation and execution of an MRP of the Aculeo Lagoon needs to be informed and evaluated by an updated version of the conceptual and numerical hydrogeological model, which must be calibrated and validated for the entire Aculeo Basin and its lagoon, considering the new data generated during the MRP execution. In this context, it will be possible to establish a scheme of continuous improvement of the current Aculeo Hydrogeological Model (AHM) constructed in this study. Periodical refinements to the AHM will have to be implemented based on the most recent information about the drilling of new wells (monitoring or pumping), as well as in relation to the activities associated with the hydraulic tests and the recovery operations of the Lagoon. With this strategy, it will be feasible to plan future MRP activities, prioritizing the acquisition of the best possible results. The new updated and improved versions of the AHM could also include changes or improvements in the Aculeo Geological Model (AGM), and in turn may count on the use of new time series of groundwater levels obtained through continuous monitoring of the target areas proposed in the MRP. In particular, for the Aculeo Lagoon Basin, it is necessary to identify with a greater level of detail (a) the most feasible areas for capturing groundwater flow within the basin, (b) the domain and boundaries of geological areas that will define a precise extent of the lagoon's recovery program, (c) the areas that will be less prone to developing groundwater drainage through the implementation of the MRP, and (d) the groundwater saturation zones that could generate the conditions conducive to the development of transient flows in the basin or in the vicinity of the Aculeo Lagoon. To improve the level of detail of the future modeling schemes, the following tasks must be completed.

- Incorporation of new geological data, as well as the identification of the most important geological faults (structures) within the domain of the basin and the Aculeo Lagoon. 
- Developing and updating a new hydrogeological database, obtained from the MRP's drilling program, which should include hydraulic tests, traces of new drilled wells, updated groundwater levels measured from historical wells, and data from new explorations.

- Compilation and interpretation of all historical information as well as that generated during the implementation of the MRP, to determine the most important hydrogeological controls on the local aquifer's hydraulic properties, and its interaction with the lagoon.

- Development, monitoring, and simulation of groundwater hydrographs using historical data and data available from new monitoring points. The available hydrographs should be evaluated and grouped according to their location and hydrogeological response.

\section{Conclusions}

Results from the analysis revealed that the lagoon-aquifer interaction responds to a natural capture-drainage or storage-drainage process, whose local surface and underground flow are dependent on the hydrological and hydrogeological conditions accumulated over time. From a hydrogeological point of view, and taking into considerations our simulation results, it is possible to suggest that the hydrodynamic balance of the lagoon has been significantly affected mainly by (1) the drying of surface tributaries and streams that provided a continuous flow of water and helped maintain the balance of the hydraulic water level of the lagoon; (2) a high existing demand on subsurface (shallow) water and groundwater in the first $30 \mathrm{~m}$ of depth, particularly demands for large-scale agricultural activities and human consumption; and (3) the climatic mega-drought, which has brought a sustained reduction of rainfall and, consequently, a gradual but significant loss of natural water recharge during the last 10 years. From the modeling results, we suggest that the current groundwater pumping rates must be immediately reduced in the whole basin, or at least in the critical areas closer to the lagoon, to minimize the impact of the ongoing and future hydro-climatic conditions on the local aquifer. The execution of an MRP to continuously monitor the lagoon will require investments estimated in about US \$10M in the first two years of implementation. However, the implementation of this type of MRP will additionally require efforts and commitment of the Chilean government to not only recover the historical water levels of the lagoon and the local aquifer, but also to recover the economy of the basin, the social well-being in the area, and most importantly, all the natural ecosystems that existed in the Aculeo Basin.

Supplementary Materials: The following are available online at http://www.mdpi.com/2073-4441/12/1/290/s1, Figure S1: (a) Daily rainfall (mm/d) and the lagoon's water levels between 2000 and 2018. The storm events larger than $40 \mathrm{~mm} / \mathrm{d}$ are less frequent after 2010; (b) Daily streamflow records $\left(\mathrm{m}^{3} / \mathrm{s}\right)$ for Pintué streamgauge and lagoon's water levels. No records of streamflow at Pintué have been available since 2011; (c) Daily Maximum (blue), average (yellow), and minimum (red) temperatures for the Aculeo Basin; (d) Monthly rainfall (mm) accumulation (left-axis), and monthly streamflow $\left(\mathrm{m}^{3} / \mathrm{s}\right)$ at Pintué streamgauge (right-axis); (e) Average Monthly Water Levels at Aculeo Lagoon (meters); (f) Monthly maximum and average temperature at Aculeo Basin. Table S1: Geodatabase used in this study. Table S2: Simplified categories of lithographic sedimentation and rock basement used in the development of the Aculeo Geological Model (AGM). Table S3: Summary of the main MODFLOW packages used in this study.

Author Contributions: Conceptualization, R.V.-P.; methodology, R.V.-P.; software, R.V.-P.; formal analysis, P.G.-C., J.B.V., and R.P.-T.; investigation, R.V.-P.; writing-original draft preparation, R.V.-P., P.G.-C., and J.B.V.; writing-review and editing, R.V.-P., P.G.-C., J.B.V., and R.P.-T.; funding acquisition, P.G.-C. All authors have read and agreed to the published version of the manuscript.

Funding: This research was funded by Gobierno Regional (GORE) Metropolitano de Santiago, División de Planificación y Desarrollo, Departamento de Planificación Regional, 2019.

Acknowledgments: The authors of this research sincerely acknowledge to GORE Metropolitano, and all Chilean students, and researchers for their support in the realization of this study. We also acknowledge the water users' organizations of the Aculeo Basin for their interest and support in the conclusions and suggestions of this study.

Conflicts of Interest: The funders of the project had no role in the design of the study; in the collection of field data, or in the analyses, or interpretation of data; in the writing of the manuscript; or in the decision to publish the results. 


\section{References}

1. Valdés-Pineda, R.; Pizarro, R.; García-Chevesich, P.; Valdés, J.B.; Olivares, C.; Vera, M.; Balocchi, F.; Pérez, F.; Vallejos, C.; Fuentes, R.; et al. Water governance in Chile: Availability, management and climate change. J. Hydrol. 2014, 519, 2538-2567. [CrossRef]

2. Villa-Martínez, R.; Villagrán, C.; Jenny, B. The last $7500 \mathrm{cal} \mathrm{yr} \mathrm{BP} \mathrm{of} \mathrm{westerly} \mathrm{rainfall} \mathrm{in} \mathrm{Central} \mathrm{Chile} \mathrm{inferred}$ from a high-resolution pollen record from Laguna Aculeo (34 S). Quat. Res. 2003, 60, 284-293. [CrossRef]

3. Valdés-Pineda, R.; Valdés, J.B.; Diaz, H.F.; Pizarro-Tapia, R. Analysis of spatio-temporal changes in annual and seasonal precipitation variability in South America-Chile and related ocean-atmosphere circulation patterns. Int. J. Climatol. 2016, 36, 2979-3001. [CrossRef]

4. Garreaud, R.D.; Alvarez-Garreton, C.; Barichivich, J.; Boisier, J.P.; Christie, D.; Galleguillos, M.; Zambrano-Bigiarini, M. The 2010-2015 megadrought in central Chile: Impacts on regional hydroclimate and vegetation. Hydrol. Earth Syst. Sci. 2017, 21, 6307-6327. [CrossRef]

5. Wilhite, D.A.; Glantz, M.H. Understanding: The drought phenomenon: The role of definitions. Water Int. 1985, 10, 111-120. [CrossRef]

6. SERNAGEOMIN. Geologic Map of Chile, Scale 1:1.000.000. 2003. Available online: https://www.sernageomin. cl/ (accessed on 14 November 2019).

7. Eridandus. Monitoreo Ambiental de Ecosistemas Acuáticos Estratégicos_Laguna de Aculeo. Informe Final-Revisión 1; Ministerio del Medio Ambiente-SEREMI del Medio Ambiente: San Diego, Chile, 2016.

8. ARANZ, G. Leapfrog Geo. 2018. Available online: http://www.leapfrog3d.com/ (accessed on 28 November 2019).

9. Harbaugh, A.W.; Banta, E.R.; Hill, M.C.; McDonald, M.G. User Guide to Modularization Concepts and the Ground-Water Flow Process. In MODFLOW-2000 the U.S. Geological Survey Modular Ground-Water Model: U.S. Geological Survey Open-File Report; USGS: Reston, VA, USA, 2000; pp. 92-121.

10. Harbaugh, A.W. MODFLOW-2005, the U.S. Geological Survey Modular Ground-Water Model-The Ground-Water Flow Process. USA Geol. Surv. Tech. Methods 2005, 6, 16.

11. Niswonger, R.G.; Panday, S.; Ibaraki, M. MODFLOW-NWT, a Newton formulation for MODFLOW-2005. USA Geol. Surv. Tech. Methods 2011, 6, 44.

12. Panday, S.; Huyakorn, P.; Therrien, R.; Nichols, R. MODFLOW-USG version 1: An unstructured grid version of MODFLOW for simulating groundwater flow. Adv. Water Resour. 2013, 25, 497-511.

13. Merritt, M.L.; Konikow, L.F. Documentation of a Computer Program to Simulate Lake-Aquifer Interaction Using the MODFLOW Ground-Water Flow Model and the MOC3D Solute-Transport Model (No. 4167); US Department of the Interior, US Geological Survey: Reston, VA, USA, 2007.

14. Hunt, R.J.; Haitjema, H.M.; Krohelski, J.T.; Feinstein, D.T. Simulating ground water-lake interactions: Approaches and insights. Groundwater 2003, 41, 227-237. [CrossRef] [PubMed]

15. Poeter, E.P.; Hill, M.C. UCODE, a computer code for universal inverse modeling. Comput. Geosci. 1999, 25, 457-462. [CrossRef]

16. Starosolszky, Ö. Lake Hydraulics. Hydrol. Sci. J. 1974, 19, 99-114. [CrossRef]

17. Dirección General de Aguas (DGA). Reevaluación de la Delimitación y de la Disponibilidad de Recursos Hídricos Subterráneos en el Acuífero El Monte, en la Región Metropolitana; Informe Técnico DARH No. 89; DGA: Santiago, Chile, 2018.

18. Pizarro, R.; García-Chevesich, P.; Valdés-Pineda, R.; Dominguez, F.; Hossain, F.; Ffolliott, P.; Olivares, C.; Morales, C.; Balocchi, F.; Bro, P. Inland water bodies in Chile can locally increase rainfall intensity. J. Hydrol. 2013, 481, 56-63. [CrossRef]

(C) 2020 by the authors. Licensee MDPI, Basel, Switzerland. This article is an open access article distributed under the terms and conditions of the Creative Commons Attribution (CC BY) license (http://creativecommons.org/licenses/by/4.0/). 